\title{
Article \\ Ultrahigh-Pressure Preparation and Catalytic Activity of MOF-Derived Cu Nanoparticles
}

\author{
Ichiro Yamane ${ }^{1}$, Kota Sato ${ }^{1}$, Ryoichi Otomo ${ }^{2}$, Takashi Yanase ${ }^{1,3}{ }^{\mathbb{D}}$, Akira Miura ${ }^{1,3}$, Taro Nagahama ${ }^{1,3}$, \\ Yuichi Kamiya ${ }^{2}$ and Toshihiro Shimada $1,3, *$ (D) \\ 1 Graduate School of Chemical Science and Engineering, Hokkaido University, Kita 13 Nishi 8, Kita-ku, \\ Sapporo 060-8628, Japan; ymn_16@eis.hokudai.ac.jp (I.Y.); ah_0403p@eis.hokudai.ac.jp (K.S.); \\ yanase42@eng.hokudai.ac.jp (T.Y.); amiura@eng.hokudai.ac.jp (A.M.); nagahama@eng.hokudai.ac.jp (T.N.) \\ 2 Section of Materials Science, Faculty of Environmental Earth Science, Hokkaido University, Kita 10, Nishi 5, \\ Kita-ku, Sapporo 060-0810, Japan; otomo@ees.hokudai.ac.jp (R.O.); kamiya@ees.hokudai.ac.jp (Y.K.) \\ 3 Division of Applied Chemistry, Faculty of Engineering, Hokkaido University, Kita 13 Nishi 8, Kita-ku, \\ Sapporo 060-8628, Japan \\ * Correspondence: shimadat@eng.hokudai.ac.jp; Tel.: +81-11-706-6576
}

Citation: Yamane, I.; Sato, K.; Otomo, R.; Yanase, T.; Miura, A.; Nagahama,

T.; Kamiya, Y.; Shimada, T.

Ultrahigh-Pressure Preparation and Catalytic Activity of MOF-Derived $\mathrm{Cu}$ Nanoparticles. Nanomaterials 2021, 11, 1040. https://doi.org/10.3390/ nano11041040

Academic Editor: Goran Drazic

Received: 22 March 2021

Accepted: 14 April 2021

Published: 19 April 2021

Publisher's Note: MDPI stays neutral with regard to jurisdictional claims in published maps and institutional affiliations.

Copyright: (c) 2021 by the authors. Licensee MDPI, Basel, Switzerland. This article is an open access article distributed under the terms and conditions of the Creative Commons Attribution (CC BY) license (https:/ / creativecommons.org/licenses/by/ $4.0 /)$.

\begin{abstract}
A metal-organic framework (MOF) consisting of $\mathrm{Cu}$-benzenetricarboxylic acid was processed under ultrahigh pressure ( $5 \mathrm{GPa}$ ) and at temperature of up to $500{ }^{\circ} \mathrm{C}$. The products were characterized with TEM, FTIR, and XAFS. The decomposition of the MOF started at $200{ }^{\circ} \mathrm{C}$ at $5 \mathrm{GPa}$. This temperature was much lower than that in the vacuum. Single-nanometer $\mathrm{Cu}$ nanoparticles were obtained in carbon matrix, which was significantly smaller than the $\mathrm{Cu}$ particles prepared at ambient pressure. The catalytic activity for Huisgen cycloaddition was examined, and the sample processed at $5 \mathrm{GPa}$ showed a much improved performance compared with that of the MOF-derived $\mathrm{Cu}$ nanoparticles prepared without high pressure.
\end{abstract}

Keywords: metal-organic framework (MOF); catalysis; copper nanoparticles; ultrahigh pressure; Huisgen cycloaddition

\section{Introduction}

Solid-state copper shows important catalytic functions in organic synthesis [1-8], graphene synthesis $[9,10]$, electrochemical reduction of carbon dioxide $[11,12]$, and purification of automobile exhaust $[13,14]$. Although group 11 elements in the periodic table show important catalytic activities [15], copper is unique among them because of its natural abundance. For heterogeneous catalysts, nanoparticles (NPs) of active components are desired because a large number of active sites are provided owing to high surface-tovolume ratio in NPs $[16,17]$. Various methods for the preparation of Cu nanoparticles have been proposed [18]. Among them, metal-organic framework (MOF)-derived metal-carbon composites are recently gathering attention because it is conceptually possible to prepare materials with designed nanostructures [19-22]. These materials are synthesized by the pyrolysis of MOFs. This method is attractive for the preparation of supported metal NPs because the active site and carrier can be synthesized simultaneously; namely, the metal cations and the ligands in the MOF are converted to metal (or metal-based) NPs and carbon matrix, respectively. However, since the carbonization process involves thermal decomposition of the organic ligands, the products are sensitive to the process parameters. Copper atoms can aggregate to make Cu NPs by pyrolysis because copper does not form stable carbides. However, previous reports show that the pyrolysis of a $\mathrm{Cu}$-containing MOF gives $\mathrm{Cu}$ NPs tens of nm [19-22]. It is desirable to reduce the size of $\mathrm{Cu}$ NPs to achieve efficient catalytic functions.

Here, we propose high-pressure and high-temperature (HPHT) synthesis to make metal nanoparticles supported on MOF-derived carbonaceous materials. In general, diffusion in the solid state is expected to be affected by applied pressure. Indeed, in the case 
of diffusion by vacancy mechanism, it has been reported that the diffusion coefficient decreases with a rise in pressure theoretically and experimentally [23-26]. Thus, it is expected that pyrolysis under high pressure can prevent nanoparticles from aggregating if their atoms diffused by the vacancy mechanism is dominant.

In this work, we carried out the HPHT treatment of copper benzenetricarboxylic acid $\left(\mathrm{Cu}-\mathrm{BTC} ; \mathrm{C}_{18} \mathrm{H}_{6} \mathrm{Cu}_{3} \mathrm{O}_{12}\right)[27,28]$ to examine the possibility of controlling the carbonization process. The products were characterized by transmission electron microscopy (TEM), X-ray diffraction (XRD), Fourier-transform infrared spectroscopy (FTIR), and X-ray absorption spectroscopy (XAS). We also prepared the samples treated under a vacuumsealed glass tube for comparison. We found that the precursor Cu-BTC was converted to a copper-carbon composite $(\mathrm{Cu} @ \mathrm{C})$ at a relatively low temperature, and the samples pyrolyzed sufficiently by the HPHT method contained fine $\mathrm{Cu}$ nanoparticles. Finally, we investigated the catalytic activity of the HPHT-treated samples in azide-alkyne Huisgen cycloaddition [5,29-32].

\section{Materials and Methods}

Cu-BTC, whose trade name is Basolite ${ }^{\circledR}$ C-300, was purchased from Aldrich. Benzylazide, phenylacetylene, 1,4-dioxane, triethylamine, 1,3,5-triisopropylbenzene, and $\mathrm{Cu}$ standard solution (1000 ppm aqueous solution) were purchased from FUJIFILM Wako Pure Chemical(Osaka, Japan) and were used without further purification.

High-pressure experiments were carried out using a cubic anvil press (180 ton, CTfactory, Tokyo, Japan) calibrated with phase transitions of bismuth [33]. The Cu-BTC powder was encapsulated in a cylindrical copper capsule, which was embedded in a $\mathrm{NaCl}$ filler and then a graphite tube heater, which were then placed in a $13 \mathrm{~mm}$ pyrophyllite cube with stainless steel electrodes. We confirmed that the copper capsule was stable and did not interfere with the results. Temperature was measured by an alumel-chromel thermocouple placed in the pyrophyllite cube, which was calibrated with another thermocouple at the sample position in a separate measurement. The sample assembly was compressed to $5 \mathrm{GPa}$. Then the cell assembly was heated by flowing electric current to the graphite heater in the sample assembly. The temperature increase took approximately $15 \mathrm{~min}$, and the temperature was kept at $200,300,400$, and $500{ }^{\circ} \mathrm{C}$ for $15 \mathrm{~min}$. Then the heating was stopped by switching off the current, and the temperature became below $50{ }^{\circ} \mathrm{C}$ only after $30 \mathrm{~s}$. After the sample was completely cooled down, the pressure was released, and the samples were collected from the cubic anvil press under ambient conditions. After grounding by a mortar and pestle, the obtained samples were used for characterization and catalytic reaction.

We synthesized not only the HPHT-treated samples but also the samples pyrolyzed under vacuum. A Cu-BTC pellet was placed in a glass tube with one side closed, and the glass tube was evacuated by a vacuum pump to $6.0 \times 10^{-1} \mathrm{~Pa}$. Subsequently, the glass tube was sealed under vacuum by burning off a part of the glass tube with a burner. The $\mathrm{Cu}-\mathrm{BTC}$ samples sealed in the glass tube were heated in a furnace at different temperatures (i.e., 200, 300, and $400^{\circ} \mathrm{C}$ ). The temperature was held for $15 \mathrm{~min}$, and then the glass tube was taken out from the furnace. After the samples cooled to room temperature, the sample was collected from the glass tube. The obtained samples were ground into powder by a mortar and pestle and were used for further experiments.

The samples carbonized were analyzed by powder XRD (MiniFlex 600, Rigaku, Tokyo, Japan), FTIR (ICPE-9000, Shimadzu, Kyoto, Japan), and TEM (JEM-2010, JEOL, Tokyo, Japan). Adsorption-desorption isotherms of $\mathrm{N}_{2}$ at $77 \mathrm{~K}$ were acquired on a Belsorp-mini instrument (BEL Japan Inc., Osaka, Japan). Specific surface areas were estimated by using the Brunauer-Emmett-Teller (BET) equation applied to the adsorption isotherms of $\mathrm{N}_{2}$. XAS spectra were taken at BL11S2 of Aichi Synchrotron Radiation Center in transmission mode. The sample and hexagonal boron nitride used as a matrix were mixed with a mortar and pestle for $20 \mathrm{~min}$, and the mixture was pelletized into a $10 \mathrm{~mm}$ pellet by using a tablet press for XAS measurement. 
The catalytic performance of these samples was evaluated for Huisgen cycloaddition illustrated in Scheme 1 following the procedure in the literature [30]. A powder catalyst $(10 \mathrm{mg})$ prepared as stated above was added to the mixture of benzylazide $(0.20 \mathrm{mmol})$, phenylacetylene $(0.22 \mathrm{mmol})$, triethylamine $(0.22 \mathrm{mmol})$, and 1,4-dioxane $(4 \mathrm{~mL})$ in a test tube. Subsequently, a stir bar was added to the test tube, and the tube was sealed by a cap. The reaction solution was heated with stirring at $60^{\circ} \mathrm{C}$ for $1 \mathrm{~h}$. Then cycloaddition was quenched by an ice bath. After the catalyst powder was removed from the mixture by filtration, the filtrate was analyzed by gas chromatography (GC) to determine the yield of the cycloaddition product. A gas chromatograph (GC-14B, Shimadzu, Kyoto, Japan) was equipped with a flame ionization detector and capillary column (TC-FFAP, $0.25 \mathrm{~mm}, 50 \mathrm{~m}$ ). 1,3,5-Triisopropylbenzene was used as an internal standard. To assign the GC peaks, the filtrate was analyzed with a GC-mass spectrometer (GCMS-QP2010SE, Shimadzu, Kyoto, Japan) equipped with a capillary column (SH-Rxi-5Sil MS, Shimadzu, Kyoto, Japan).

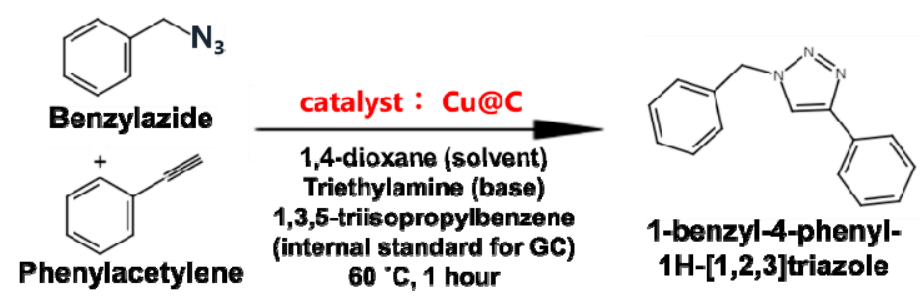

Scheme 1. Huisgen cycloaddition for the evaluation of catalytic performance.

Copper contents in the samples were determined by inductively coupled plasma optical emission spectroscopy (ICP-OES). The samples were completely dissolved in concentrated nitric acid under reflux conditions, and the diluted sample solutions were used for ICP-OES (ICPE-9000, Shimadzu, Kyoto, Japan) measurement. The detail is described in Supplementary Materials.

\section{Results and Discussion}

The powder XRD patterns and FTIR spectra were acquired to characterize and identify the as-synthesized samples. Figure $1 \mathrm{a}, \mathrm{b}$ shows the XRD patterns of the MOF-derived samples prepared by the HPHT treatment and pyrolysis in a vacuum-sealed glass tube, respectively. The figure also illustrates that of the precursor $\mathrm{Cu}-\mathrm{BTC}$ for comparison. As shown in Figure $1 \mathrm{a}$, the three characteristic peaks at $2 \theta=43.4^{\circ}, 50.5^{\circ}$, and $74.1^{\circ}$ are observed in all HPHT-treated samples, which are absent in the precursor $\mathrm{Cu}$-BTC. These diffraction peaks correspond to (110), (200), and (220) crystalline planes of metallic copper, respectively. No peaks attributed to $\mathrm{CuO}$ and $\mathrm{Cu}_{2} \mathrm{O}$ were observed. It is reported that the framework structure of $\mathrm{Cu}$-BTC is robust at room temperature and does not become amorphous below $30 \mathrm{GPa}$ [34]. The appearance of diffraction peaks from $\mathrm{Cu}$ indicates that the pyrolysis of $\mathrm{Cu}$-BTC at $5 \mathrm{GPa}$ started at $200{ }^{\circ} \mathrm{C}$ or below, resulting in the formation of metallic copper and carbonized BTC framework. Besides, some peaks of the precursor Cu-BTC were maintained in the low-angle region at $5 \mathrm{GPa} / 200{ }^{\circ} \mathrm{C}$ and $5 \mathrm{GPa} / 300{ }^{\circ} \mathrm{C}$. This suggests that the partly collapsed Cu-BTC framework may remain in these samples.

On the other hand, the XRD patterns of the samples obtained in the vacuum-sealed glass tube show a different trend from those of the HPHT-treated ones (Figure 1b). For the samples obtained at 200 and $300{ }^{\circ} \mathrm{C}$, the peaks due to not metallic $\mathrm{Cu}$ but the partially decomposed precursor Cu-BTC were observed. The peaks became broader, and the intensities significantly changed with temperature increase, indicating that heat treatments decreased the crystallinity with no production of $\mathrm{Cu}$ particles. For the sample obtained at $400{ }^{\circ} \mathrm{C}$, three diffraction peaks of metallic $\mathrm{Cu}$ were observed as in the case of HPHT-treated samples. Therefore, it is apparent that the Cu-BTC pyrolyzed and carbonized at $400{ }^{\circ} \mathrm{C}$ in the vacuum-sealed glass tube. 

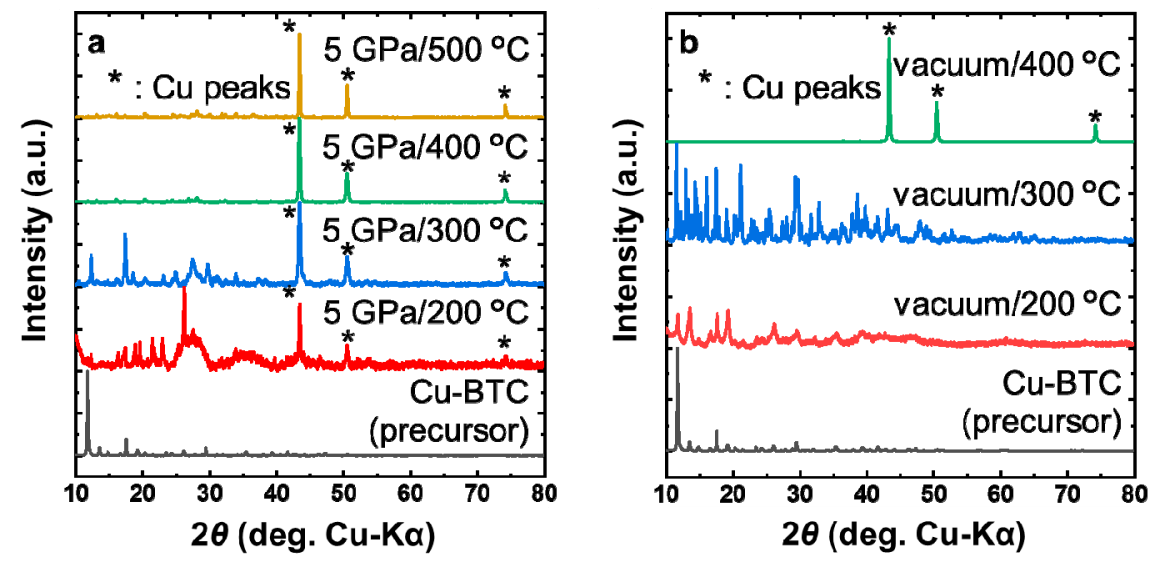

Figure 1. X-ray diffraction patterns of (a) the HPHT samples and (b) the samples pyrolyzed in the vacuum-sealed glass tubes. The peaks marked with an asterisk $\left(^{*}\right)$ at $2 \theta=43.4^{\circ}, 50.5^{\circ}$, and $74.1^{\circ}$ are assigned to (110), (200), and (220) crystalline planes of metallic $\mathrm{Cu}$, respectively.

Figure 2a,b shows the IR spectra of the HPHT-treated samples and those heated in a vacuum-sealed glass tube, respectively. The IR spectrum of the precursor Cu-BTC is given for comparison. Several characteristic bands are observed in the spectrum of the precursor $\mathrm{Cu}$-BTC. The band at $486 \mathrm{~cm}^{-1}$ corresponds to the $\mathrm{Cu}-\mathrm{O}$ stretching vibration. The two bands at 730 and $760 \mathrm{~cm}^{-1}$ correspond to the out-of-plane $\mathrm{C}-\mathrm{H}$ bending vibration of the benzene rings of the $\mathrm{Cu}-\mathrm{BTC}$, while the band at $1110 \mathrm{~cm}^{-1}$ corresponds to their in-plane $\mathrm{C}-\mathrm{H}$ bending vibration. The two bands at $1373 / 1449 \mathrm{~cm}^{-1}$ and $1571 / 1630 \mathrm{~cm}^{-1}$ represent the symmetric and asymmetric stretching vibration of the carboxylate groups, respectively [34]. For the spectra of all the HPHT-treated samples, the $\mathrm{Cu}-\mathrm{O}$ band disappears as shown in Figure 2a, which means that $\mathrm{Cu}^{2+}$ no longer coordinated with carboxyl groups $\mathrm{COO}^{-}$and the crystal structure of $\mathrm{Cu}-\mathrm{BTC}$ was collapsed. The bands corresponding to the benzene rings and carboxylate groups gradually disappeared as the temperature was increased. This indicates that the pyrolysis of the BTC (i.e., $\left.\mathrm{C}_{6} \mathrm{H}_{3}\left(\mathrm{COO}^{-}\right)_{3}\right)$ proceeded at temperatures higher than that for metallic $\mathrm{Cu}$ formation. It is considered that the benzene ring decomposed to carbonaceous substances, and $\mathrm{COO}^{-}$was eliminated as $\mathrm{CO}_{2}$. This decarboxylation was associated with the reduction of $\mathrm{Cu}^{2+}$ to metallic $\mathrm{Cu}$. This is consistent with the results of XRD. Besides, the IR spectra indicate that a small amount of benzene ring and carboxy groups remained in the samples treated at 400 and $500{ }^{\circ} \mathrm{C}$ under $5 \mathrm{GPa}$, although their XRD patterns exhibited only metallic $\mathrm{Cu}$ peaks. It means that the carbonized matrix was amorphous.
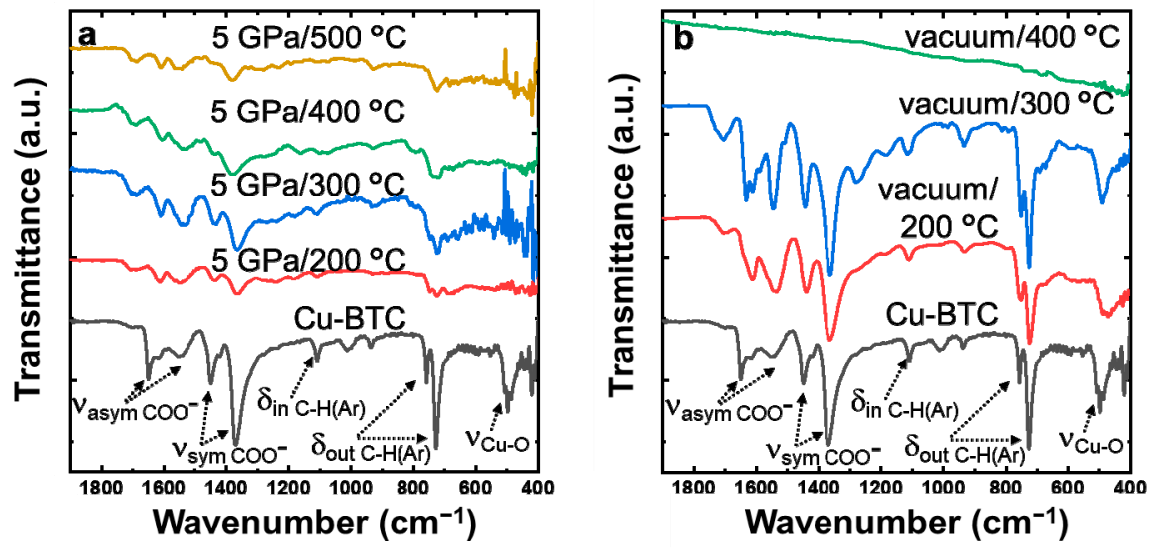

Figure 2. FTIR spectra of (a) the HPHT samples and (b) the samples pyrolyzed in the vacuum-sealed glass tubes. Marks of IR peaks $v, \delta$, and Ar in the figures denote stretching, bending, and the benzene ring, respectively. 
The samples heated at 200 and $300{ }^{\circ} \mathrm{C}$ in the vacuum-sealed glass tube had IR bands similar to those of the precursor $\mathrm{Cu}-\mathrm{BTC}$, while no such bands were observed in the sample obtained at $400{ }^{\circ} \mathrm{C}$. This result indicates that the $\mathrm{Cu}-\mathrm{BTC}$ was not pyrolyzed at $300{ }^{\circ} \mathrm{C}$ or below, while the benzene ring was fully converted to carbon materials by pyrolysis at $400{ }^{\circ} \mathrm{C}$. This is also consistent with the result of XRD.

The copper content of the synthesized samples was examined by ICP-OES. As shown in Table 1, the relative $\mathrm{Cu}$ content increased with an increase in the treatment temperature for the HPHT-treated samples. It reflects the progress of pyrolysis associated with the loss of carbon species, which is consistent with the results of XRD and FTIR. The Cu contents of $5 \mathrm{GPa} / 200^{\circ} \mathrm{C}$ and $5 \mathrm{GPa} / 300^{\circ} \mathrm{C}$ samples were lower than that of the precursor $\mathrm{Cu}-\mathrm{BTC}$ $(31.5 \mathrm{wt} \%)$, and this may be caused by moisture absorption on the samples. On the other hand, for the samples obtained in the vacuum-sealed glass tube, the $\mathrm{Cu}$ content of the unpyrolyzed ones $\left(<300{ }^{\circ} \mathrm{C}\right)$ was almost the same as that of the Cu-BTC. Subsequently, the $\mathrm{Cu}$ content was increased drastically by heating at $400{ }^{\circ} \mathrm{C}$, indicating the occurrence of the pyrolyzation.

Table 1. $\mathrm{Cu}$ content determined by ICP-OES of MOF-derived $\mathrm{Cu} @ \mathrm{C}$ materials.

\begin{tabular}{cc}
\hline Scheme & Cu Content \\
\hline $5 \mathrm{GPa} / 500^{\circ} \mathrm{C}$ & $63 \mathrm{wt} \%$ \\
$5 \mathrm{GPa} / 400^{\circ} \mathrm{C}$ & $56 \mathrm{wt} \%$ \\
$5 \mathrm{GPa} / 300^{\circ} \mathrm{C}$ & $27 \mathrm{wt} \%$ \\
$5 \mathrm{GPa} / 200^{\circ} \mathrm{C}$ & $25 \mathrm{wt} \%$ \\
$\operatorname{Vacuum} / 400^{\circ} \mathrm{C}$ & $54 \mathrm{wt} \%$ \\
Vacuum $/ 300^{\circ} \mathrm{C}$ & $30 \mathrm{wt} \%$ \\
Vacuum $/ 200^{\circ} \mathrm{C}$ & $30 \mathrm{wt} \%$ \\
\hline
\end{tabular}

Previous studies have reported that $\mathrm{Cu}$-BTC decomposes at $>400{ }^{\circ} \mathrm{C}$ under ambient pressure [35-38]. Our experiments show that heating of $\mathrm{Cu}-\mathrm{BTC}$ in vacuum had the same trend. However, under high pressure (5 GPa), Cu-BTC started to decompose and produce metallic copper at a lower temperature than those conditions. This suggests that the high pressure shifts the equilibrium to the side to decompose $\mathrm{Cu}-\mathrm{BTC}$ to produce $\mathrm{Cu}$.

The morphology of $\mathrm{Cu}$ particles in the samples was examined by TEM. As shown in Figure 3, the samples sufficiently pyrolyzed contain $\mathrm{Cu}$ as NPs in the carbon matrix. For the samples synthesized at $5 \mathrm{GPa} / 500{ }^{\circ} \mathrm{C}$ and $5 \mathrm{GPa} / 400^{\circ} \mathrm{C}$, the sizes of $\mathrm{Cu}$ NPs are around 5 and $10 \mathrm{~nm}$, respectively, which are smaller than that pyrolyzed in a vacuumsealed glass tube. Furthermore, the $\mathrm{Cu}$ NPs are also smaller than the values of the reported Cu-BTC-derived materials pyrolyzed at ambient pressure [35-37]. Therefore, high-pressure treatments enable the $\mathrm{Cu}$ NPs to prevent from sintering without any special templates or support materials. This pressure effect can be originated from the pressure dependency of the diffusion coefficient.

The samples pyrolyzed sufficiently were further characterized by X-ray absorption near edge structure (XANES) in order to evaluate the valence state of $\mathrm{Cu}$ in the NPs. The normalized XANES spectra of these samples and references $\left(\mathrm{Cu}-\mathrm{foil}, \mathrm{Cu}_{2} \mathrm{O}\right.$, and $\left.\mathrm{CuO}\right)$ are shown in Figure 4. The sample synthesized in the vacuum-sealed glass tube at $400{ }^{\circ} \mathrm{C}$ showed a similar XANES spectrum to that of the $\mathrm{Cu}$-foil in the spectrum, whereas the samples prepared at $5 \mathrm{GPa} / 400{ }^{\circ} \mathrm{C}$ and $5 \mathrm{GPa} / 500{ }^{\circ} \mathrm{C}$ were quite different from those of the references. The main absorption peak of the sample prepared at $5 \mathrm{GPa}$ slightly shifted toward higher energy, and the slope on the rising of the peak became smaller than that of the Cu-foil. It is in contrast to the fact that only metal $\mathrm{Cu}$ peaks were observed in the XRD patterns of all these samples. This indicates that the spectra of the HPHT-treated samples contained the component for those of $\mathrm{Cu}_{2} \mathrm{O}$ and $\mathrm{CuO}$. Thus, it is revealed that the surface of $\mathrm{Cu}$ NPs in HPHT-treated samples was partially oxidized. The XANES spectra were curve-fitted by linear combination of the spectra of the $\mathrm{Cu}$-foil, $\mathrm{Cu}_{2} \mathrm{O}$, and $\mathrm{CuO}$. The result is shown in Table 2 and Figure S1. The detail of the curve fitting is shown in Supporting Information. 


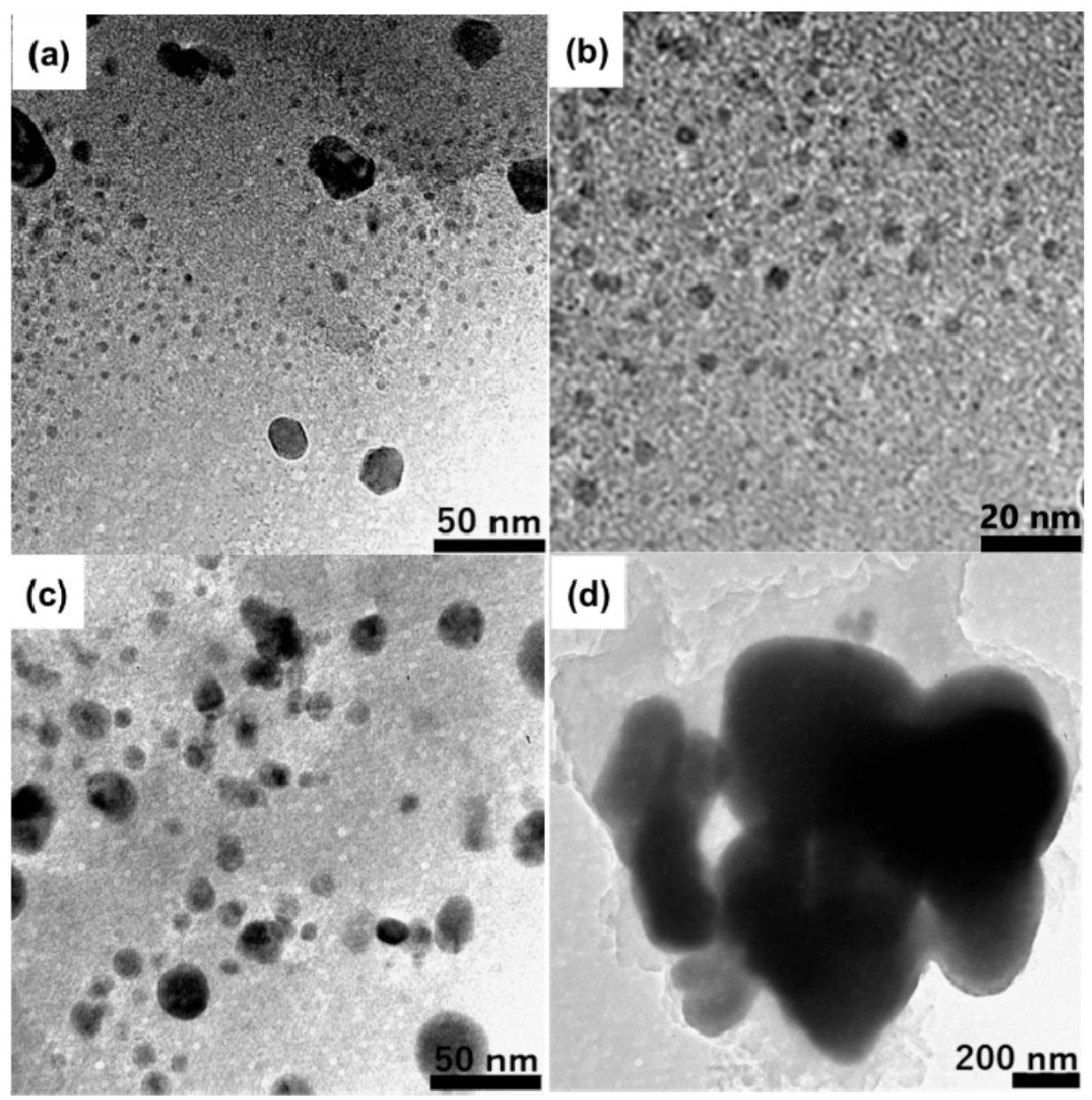

Figure 3. TEM images of (a) Cu@C synthesized at $5 \mathrm{GPa} / 500^{\circ} \mathrm{C},(\mathbf{b})$ magnified view of (a), (c) $\mathrm{Cu} @ \mathrm{C}$ synthesized at $5 \mathrm{GPa} / 400{ }^{\circ} \mathrm{C}$, and (d) $\mathrm{Cu} @ \mathrm{C}$ synthesized in a vacuum-sealed glass tube (vacuum $/ 400{ }^{\circ} \mathrm{C}$ ).

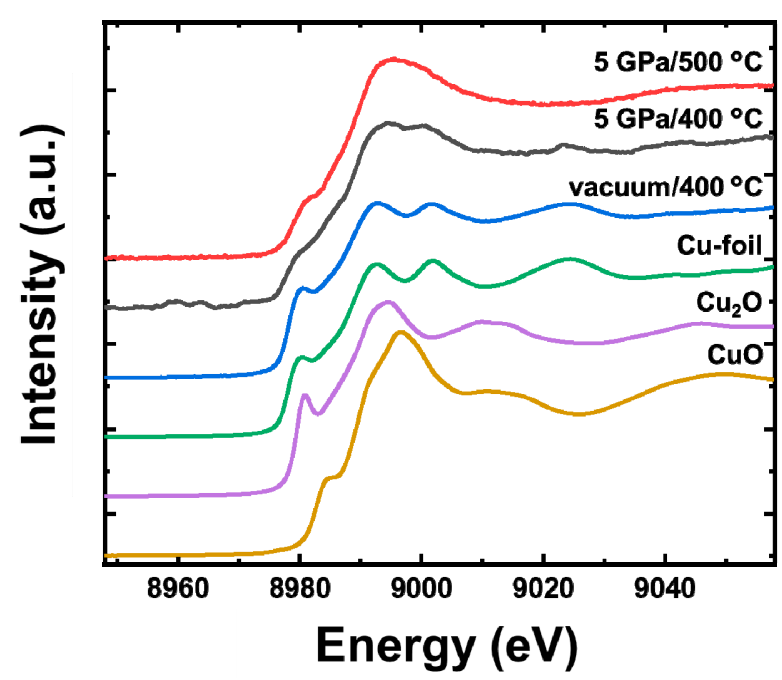

Figure 4. XANES spectra of MOF-derived $\mathrm{Cu} @ \mathrm{C}$ and reference samples. 
Table 2. XANES analysis for Cu valency of MOF-derived Cu@C materials.

\begin{tabular}{cccc}
\hline \multirow{2}{*}{ Synthesis Conditions } & $\mathbf{C u}$ & $\mathrm{Cu}_{\mathbf{2}} \mathbf{O}$ & $\mathrm{CuO}$ \\
\cline { 2 - 4 } & Atomic $\%$ & Atomic $\%$ & Atomic \% \\
\hline $5 \mathrm{GPa} / 500{ }^{\circ} \mathrm{C}$ & $26.2 \pm 1.9$ & $22.6 \pm 2.3$ & $51.2 \pm 4.5$ \\
$5 \mathrm{GPa} / 400{ }^{\circ} \mathrm{C}$ & $44.9 \pm 4.8$ & $31.9 \pm 5.7$ & $23.2 \pm 8.3$ \\
Vacuum $/ 400^{\circ} \mathrm{C}$ & $79.3 \pm 1.4$ & $20.7 \pm 3.0$ & $0.0 \pm 0.9$ \\
\hline
\end{tabular}

The porous nature of the carbonaceous matrix in these samples was characterized by $\mathrm{N}_{2}$ adsorption measurements, with the specific surface areas (SSAs) calculated by the BET method. The results are shown in Table 3. Only the one synthesized at $200{ }^{\circ} \mathrm{C}$ had mesopores as in the precursor $\mathrm{Cu}$-BTC, while the other ones showed macropores. The rather complicated behavior of the SSAs shown in Table 3 can be explained as follows. In the vacuum-treated samples, the SSAs decreased significantly by the deterioration in crystallinity at 200 and $300{ }^{\circ} \mathrm{C}$. At $400{ }^{\circ} \mathrm{C}$, the pyrolysis proceeded, and $\mathrm{CO}_{2}$ and other volatile species were formed, resulting in channels in the products and in an increase in the SSAs. In the HPHT-treated samples, very small SSAs at $200{ }^{\circ} \mathrm{C}$ can be explained by the collapse of the pores of a MOF by decomposition under pressure. The increase of SSAs from 300 to $400{ }^{\circ} \mathrm{C}$ can be explained by the pores created by trails of $\mathrm{Cu}$ NPs during the aggregation. At $500{ }^{\circ} \mathrm{C}$, the $\mathrm{Cu}$ aggregation is hindered by the quick carbonization of the MOF ligand, thus preventing the formation of long connected channels.

Table 3. Surface areas measured by $\mathrm{N}_{2}$ adsorption and the BET method of MOF-derived Cu@C materials, pristine $\mathrm{Cu}-\mathrm{BTC}$.

\begin{tabular}{cc}
\hline Synthesis Conditions of Catalysts & Surface Area $\left(\mathbf{m}^{\mathbf{2}} \mathbf{g}^{-\mathbf{1}}\right)$ \\
\hline $5 \mathrm{GPa} / 500^{\circ} \mathrm{C}$ & 6.7 \\
$5 \mathrm{GPa} / 400^{\circ} \mathrm{C}$ & 22.6 \\
$5 \mathrm{GPa} / 300^{\circ} \mathrm{C}$ & 9.1 \\
$5 \mathrm{GPa} / 200^{\circ} \mathrm{C}$ & 0.4 \\
$\operatorname{Vacuum} / 400^{\circ} \mathrm{C}$ & 13.6 \\
Vacuum $/ 300^{\circ} \mathrm{C}$ & 9.7 \\
Vacuum $/ 200^{\circ} \mathrm{C}$ & 124.6 \\
$\mathrm{Cu}-\mathrm{BTC}$ & 937.6 \\
\hline
\end{tabular}

Huisgen cycloaddition is one of the most representative click reactions that produce 1,2,3-triazole and is accelerated by $\mathrm{Cu}$ catalysts [18,30]. The yields of the product in Huisgen cycloaddition are shown in Table 4.

Table 4. Yields of the product in Huisgen cycloaddition over by MOF-derived Cu@C catalysts.

\begin{tabular}{cc}
\hline Synthesis Conditions of Catalysts & Yield \\
\hline $5 \mathrm{GPa} / 500^{\circ} \mathrm{C}$ & $28 \%$ \\
$5 \mathrm{GPa} / 400^{\circ} \mathrm{C}$ & $18 \%$ \\
$5 \mathrm{GPa} / 300^{\circ} \mathrm{C}$ & $16 \%$ \\
$5 \mathrm{GPa} / 200^{\circ} \mathrm{C}$ & $0 \%$ \\
Vacuum $/ 400^{\circ} \mathrm{C}$ & $0 \%$ \\
Vacuum $/ 300^{\circ} \mathrm{C}$ & $0 \%$ \\
Vacuum $/ 200^{\circ} \mathrm{C}$ & $0 \%$ \\
Blank (no catalyst) & $0 \%$ \\
\hline
\end{tabular}

The HPHT pyrolyzed samples exhibited catalytic activity, which was improved with a rise in treatment temperature. On the other hand, vacuum-pyrolyzed samples did not show catalytic activity. We can consider three factors governing the catalytic activity in this case. The first is the exposure of the $\mathrm{Cu}$ NP surface to the outside. If the carbon species cover the $\mathrm{Cu}$ NPs, the $\mathrm{Cu}$ NPs do not work as catalysts. Under a confined environment, the 
decomposed species may cover the surface of the Cu NPs. This explains the result in which the samples obtained in the vacuum-sealed glass tube did not show catalytic activity. In contrast, the HPHT environment was in the air, and carbonaceous matrix species covering the $\mathrm{Cu}$ NP can be partially combusted. Actually, we can see some small gaps between the $\mathrm{Cu}$ NPs and the surrounding matrix in the TEM images of the HPHT-treated samples (Figure $3 a-c)$, whereas the samples treated in the vacuum-sealed glass tube were totally covered by carbon matrix (Figure 3d).

The second factor is the surface-to-volume ratio of the $\mathrm{Cu}$ NPs. In general, $\mathrm{Cu}$ NPs easily sinter and aggregate at $>300{ }^{\circ} \mathrm{C}$, leading to a decrease in catalytic activity. In this work, however, we succeeded in inhibiting the diffusion of $\mathrm{Cu}$ atoms by treating them under high pressure, thus preventing the aggregation. This effect makes it possible to increase the relative copper loading ratio contained in the samples without sintering the particles, which we consider to be responsible for the increase in the catalytic activity of the HPHT samples treated at higher temperatures.

The third factor is the oxidation state of the NP surface. It has been reported that not only $\mathrm{CuI}$ salts but also mixed $\mathrm{Cu} / \mathrm{Cu}$-oxide NPs or $\mathrm{CuO}$ can act as catalysts $[1,5,30,39]$. The XANES results showed that the surfaces of the $\mathrm{Cu}$ NPs in the samples synthesized at $5 \mathrm{GPa} / 400{ }^{\circ} \mathrm{C}$ and $5 \mathrm{GPa} / 500{ }^{\circ} \mathrm{C}$ were partly oxidized, forming mixed $\mathrm{Cu} / \mathrm{Cu}$-oxide NPs. The $5 \mathrm{GPa} / 500{ }^{\circ} \mathrm{C}$ sample was more oxidized. These results are in accordance with the catalytic activity. The high oxidation ratio of the HPHT $500{ }^{\circ} \mathrm{C}$ sample is explained by the high surface-to-volume ratio of the smallest $\mathrm{Cu}$ NPs among the samples.

The second and third factors come from the small size of the Cu NPs, which originated from the inhibited diffusion of $\mathrm{Cu}$ atoms at a high-pressure condition during the decomposition of the MOF. The present result offers a strategy for the preparation of highly active catalysts based on metal nanoparticles synthesized from the decomposition of the MOF and metal complex-based materials.

\section{Conclusions}

We examined the HPHT treatment of the $\mathrm{Cu}$-containing MOF (Cu-BTC) to prepare $\mathrm{Cu}$ NPs supported on the carbonaceous material. The aggregation of $\mathrm{Cu}$ NPs was prevented, and sub-10 nm NPs were obtained. It was found that the decomposition temperature of Cu-BTC was lowered from $400{ }^{\circ} \mathrm{C}$ at ambient pressure or vacuum to $200{ }^{\circ} \mathrm{C}$ at $5 \mathrm{GPa}$. The $\mathrm{Cu} @ \mathrm{C}$ samples prepared by the HPHT treatment showed high activity for Huisgen cycloaddition reaction.

Supplementary Materials: The following are available online at https:/ / www.mdpi.com/article/10.339 0/nano11041040/s1, 1. Preparation of ICP-OES Samples; 2. (Figure S1) Curve Fitting of XANES spectra.

Author Contributions: I.Y. was involved in all parts of this paper, including data analysis and writing. K.S. did the high-pressure experiments. R.O. and Y.K. contributed in the catalysis part of the research. A.M. contributed in the XAS part. T.Y., T.N. and T.S. planned the research, helped in the analysis of the results, and edited the manuscript. All authors have read and agreed to the published version of the manuscript.

Funding: The present study was partly supported by KAKENHI 17H03380 from MEXT, Japan. The instrumental analyses were supported by the Nanotechnology Initiative, MEXT, Japan. XAS spectra were taken at Aichi Synchrotron Radiation Center with approval number 2020D1014.

Data Availability Statement: The data is available on reasonable request from the corresponding author.

Conflicts of Interest: The authors declare no conflict of interest.

\section{References}

1. Hassan, J.; Sévignon, M.; Gozzi, C.; Schulz, E.; Lemaire, M. Aryl-Aryl Bond Formation One Century after the Discovery of the Ullmann Reaction. Chem. Rev. 2002, 102, 1359-1469. [CrossRef]

2. Thathagar, M.B.; Beckers, J.; Rothenberg, G. Copper-Catalyzed Suzuki Cross-Coupling Using Mixed Nanocluster Catalysts. J. Am. Chem. Soc. 2002, 124, 11858-11859. [CrossRef] 
3. Thathagar, M.B.; Beckers, J.; Rothenberg, G. Palladium-Free and Ligand-Free Sonogashira Cross-Coupling. Green Chem. 2004, 6, 215-218. [CrossRef]

4. Lakshmi Kantam, M.; Swarna Jaya, V.; Jaya Lakshmi, M.; Reddy, B.R.; Choudary, B.M.; Bhargava, S.K. Alumina Supported Copper Nanoparticles for Aziridination and Cyclopropanation Reactions. Catal. Commun. 2007, 8, 1963-1968. [CrossRef]

5. Alonso, F.; Moglie, Y.; Radivoy, G.; Yus, M. Multicomponent Synthesis of 1,2,3-Triazoles in Water Catalyzed by Copper Nanoparticles on Activated Carbon. Adv. Synth. Catal. 2010, 352, 3208-3214. [CrossRef]

6. Kidwai, M.; Mishra, N.K.; Bansal, V.; Kumar, A.; Mozumdar, S. Cu-Nanoparticle Catalyzed O-Arylation of Phenols with Aryl Halides via Ullmann Coupling. Tetrahedron Lett. 2007, 48, 8883-8887. [CrossRef]

7. Bhadra, S.; Saha, A.; Ranu, B.C. One-Pot Copper Nanoparticle-Catalyzed Synthesis of S-Aryl- and S-Vinyl Dithiocarbamates in Water: High Diastereoselectivity Achieved for Vinyl Dithiocarbamates. Green Chem. 2008, 10, 1224-1230. [CrossRef]

8. Kidwai, M.; Bansal, V.; Saxena, A.; Aerry, S.; Mozumdar, S. Cu-Nanoparticles: Efficient Catalysts for the Oxidative Cyclization of Schiffs' Bases. Tetrahedron Lett. 2006, 47, 8049-8053. [CrossRef]

9. Li, X.; Cai, W.; An, J.; Kim, S.; Nah, J.; Yang, D.; Piner, R.; Velamakanni, A.; Jung, I.; Tutuc, E.; et al. Large-Area Synthesis of High-Quality and Uniform Graphene Films on Copper Foils. Science 2009, 324, 1312-1314. [CrossRef]

10. Sun, Z.; Yan, Z.; Yao, J.; Beitler, E.; Zhu, Y.; Tour, J.M. Growth of Graphene from Solid Carbon Sources. Nature 2010, 468, 549-552. [CrossRef] [PubMed]

11. Lu, Q.; Rosen, J.; Zhou, Y.; Hutchings, G.S.; Kimmel, Y.C.; Chen, J.G.; Jiao, F. A Selective and Efficient Electrocatalyst for Carbon Dioxide Reduction. Nat. Commun. 2014, 5, 1-6. [CrossRef]

12. Kortlever, R.; Shen, J.; Schouten, K.J.P.; Calle-Vallejo, F.; Koper, M.T.M. Catalysts and Reaction Pathways for the Electrochemical Reduction of Carbon Dioxide. J. Phys. Chem. Lett. 2015, 6, 4073-4082. [CrossRef] [PubMed]

13. Iwamoto, M.; Hamada, H. Removal of Nitrogen Monoxide From Exhaust Gases Through Novel Catalytic Processes. Catal. Today 1991, 10, 57-71. [CrossRef]

14. Kašpar, J.; Fornasiero, P.; Hickey, N. Automotive: Catalytic Converters Current Status. Catal. Today 2003, 77, 419-449. [CrossRef]

15. McNulty, J.; Keskar, K.; Vemula, R. The FirstWell-Defined Silver(I)-Complex-Catalyzed Cycloaddition of Azides onto Terminal Alkynes at Room Temperature. Chem. Eur. J. 2011, 17, 14727-14730. [CrossRef]

16. Astruc, D.; Lu, F.; Aranzaes, J.R. Nanoparticles as Recyclable Catalysts: The Frontier between Homogeneous and Heterogeneous Catalysis. Angew. Chem. Int. Ed. 2005, 44, 7852-7872. [CrossRef] [PubMed]

17. Reetz, M.T.; Maase, M. Redox-Controlled Size-Selective Fabrication of Nanostructured Transition Metal Colloids. Adv. Mater. 1999, 11, 773-777. [CrossRef]

18. Ranu, B.C.; Dey, R.; Chatterjee, T.; Ahammed, S. Copper Nanoparticle-Catalyzed Carbon-Carbon and Carbon-Heteroatom Bond Formation with a Greener Perspective. ChemSusChem 2012, 5, 22-44. [CrossRef] [PubMed]

19. Shen, K.; Chen, X.; Chen, J.; Li, Y. Development of MOF-Derived Carbon-Based Nanomaterials for Efficient Catalysis. ACS Catal. 2016, 6, 5887-5903. [CrossRef]

20. Kim, A.; Muthuchamy, N.; Yoon, C.; Joo, S.H.; Park, K.H. MOF-Derived Cu@Cu $\mathrm{Cu}_{2} \mathrm{O}$ Nanocatalyst for Oxygen Reduction Reaction and Cycloaddition Reaction. Nanomaterials 2018, 8, 138. [CrossRef]

21. Han, A.; Wang, B.; Kumar, A.; Qin, Y.; Jin, J.; Wang, X.; Yang, C.; Dong, B.; Jia, Y.; Liu, J.; et al. Recent Advances for MOF-Derived Carbon-Supported Single-Atom Catalysts. Small Methods 2019, 3. [CrossRef]

22. Liu, H.; Zhang, S.; Liu, Y.; Yang, Z.; Feng, X.; Lu, X.; Huo, F. Well-Dispersed and Size-Controlled Supported Metal Oxide Nanoparticles Derived from MOF Composites and Further Application in Catalysis. Small 2015, 11, 3130-3134. [CrossRef]

23. Candland, C.T.; Decker, D.L.; Vanfleet, H.B. Interstitial Diffusion of Copper in Lead at Pressures up to 56 Kbar. Phys. Rev. B 1972, 5, 2085-2094. [CrossRef]

24. Peterson, N.L. Self-Diffusion in Pure Metals. J. Nucl. Mater. 1978, 69-70, 3-37. [CrossRef]

25. Wang, J.; Chen, B.; Williams, Q.; Manghnani, M.H. Short- and Intermediate-Range Structure and Dynamics of Fe-Ni-C Liquid Under Compression. Front. Earth Sci. 2019, 7, 258. [CrossRef]

26. Rein, G.; Mehrer, H.; Mehrer, H. Effect of Hydrostatic Pressure and Temperature on the Self-Diffusion Rate in Single Crystals of Silver and Gold. Philos. Mag. A Phys. Condens. Matter Struct. Defects Mech. Prop. 1982, 45, 467-492. [CrossRef]

27. Chui, S.S.Y.; Lo, S.M.F.; Charmant, J.P.H.; Orpen, A.G.; Williams, I.D. A Chemically Functionalizable Nanoporous Material $\left[\mathrm{Cu}_{3}(\mathrm{TMA})_{2}\left(\mathrm{H}_{2} \mathrm{O}\right)_{3}\right](\mathrm{N})$. Science 1999, 283, 1148-1150. [CrossRef] [PubMed]

28. Chen, H.Y.; Wee, G.; Al-Oweini, R.; Friedl, J.; Tan, K.S.; Wang, Y.; Wong, C.L.; Kortz, U.; Stimming, U.; Srinivasan, M. A Polyoxovanadate as an Advanced Electrode Material for Supercapacitors. ChemPhysChem 2014, 15, 2162-2169. [CrossRef] [PubMed]

29. Molteni, G.; Bianchi, C.L.; Marinoni, G.; Santo, N.; Ponti, A. Cu/Cu-Oxide Nanoparticles as Catalyst in the "Click" Azide-Alkyne Cycloaddition. New J. Chem. 2006, 30, 1137-1139. [CrossRef]

30. Lipshutz, B.H.; Taft, B.R. Heterogeneous Copper-in-Charcoal-Catalyzed Click Chemistry. Angew. Chem. Int. Ed. 2006, 45, 8235-8238. [CrossRef]

31. Zhang, X.; Li, H.; You, L.; Tang, Y.; Hsung, R.P. Copper Salt-Catalyzed Azide-[3 + 2] Cycloadditions of Ynamides and Bis-Ynamides. Adv. Synth. Catal. 2006, 348, 2437-2442. [CrossRef]

32. Yan, Z.Y.; Zhao, Y.B.; Fan, M.J.; Liu, W.M.; Liang, Y.M. General Synthesis of (1-Substituted-1H-1,2,3-Triazol-4-Ylmethyl)Dialkylamines via a Copper(I)-Catalyzed Three-Component Reaction in Water. Tetrahedron 2005, 61, 9331-9337. [CrossRef] 
33. Knibbe, J.S.; Luginbühl, S.M.; Stoevelaar, R.; van der Plas, W.; van Harlingen, D.M.; Rai, N.; Steenstra, E.S.; van de Geer, R.; van Westrenen, W. Calibration of a multi-anvil high-pressure apparatus to simulate planetary interior conditions. EPJ Techn. Instrum. 2018, 5, 5. [CrossRef]

34. Dong, Z.; Mi, Z.; Shi, W.; Jiang, H.; Zheng, Y.; Yang, K. High Pressure Effects on Hydrate Cu-BTC Investigated by Vibrational Spectroscopy and Synchrotron X-Ray Diffraction. RSC Adv. 2017, 7, 55504-55512. [CrossRef]

35. Zhang, J.; An, B.; Hong, Y.; Meng, Y.; Hu, X.; Wang, C.; Lin, J.; Lin, W.; Wang, Y. Pyrolysis of Metal-Organic Frameworks to Hierarchical Porous $\mathrm{Cu} / Z n-N a n o p a r t i c l e @ c a r b o n ~ M a t e r i a l s ~ f o r ~ E f f i c i e n t ~ \mathrm{CO}_{2}$ Hydrogenation. Mater. Chem. Front. 2017, 1, 2405-2409. [CrossRef]

36. Cheng, J.; Xuan, X.; Yang, X.; Zhou, J.; Cen, K. Selective Reduction of $\mathrm{CO}_{2}$ to Alcohol Products on Octahedral Catalyst of Carbonized $\mathrm{Cu}(\mathrm{BTC})$ Doped with Pd Nanoparticles in a Photoelectrochemical Cell. Chem. Eng. J. 2019, 358, 860-868. [CrossRef]

37. Weng, Y.; Guan, S.; Wang, L.; Lu, H.; Meng, X.; Waterhouse, G.I.N.; Zhou, S. Defective Porous Carbon Polyhedra Decorated with Copper Nanoparticles for Enhanced NIR-Driven Photothermal Cancer Therapy. Small 2020, 16, 1-10. [CrossRef]

38. Zhou, X.; Zhai, X.; Ge, G.; Dan, J.; Pan, K.; Tian, J.; Sun, R.; Dai, B.; Pfeiffer, H.; Yu, F. Enhanced Selective Catalytic Reduction of $\mathrm{NO}$ with $\mathrm{CO}$ over $\mathrm{Cu} / \mathrm{C}$ Nanoparticles Synthetized from a Cu-Benzene-1,3,5-Tricarboxylate Metal Organic Framework by a Continuous Spray Drying Process. Chem. Eng. J. 2020, 388, 124270. [CrossRef]

39. Bock, V.D.; Hiemstra, H.; Van Maarseveen, J.H. Cu I-Catalyzed Alkyne-Azide "Click" Cycloadditions from a Mechanistic and Synthetic Perspective. Eur. J. Org. Chem. 2006, 2006, 51-68. [CrossRef] 